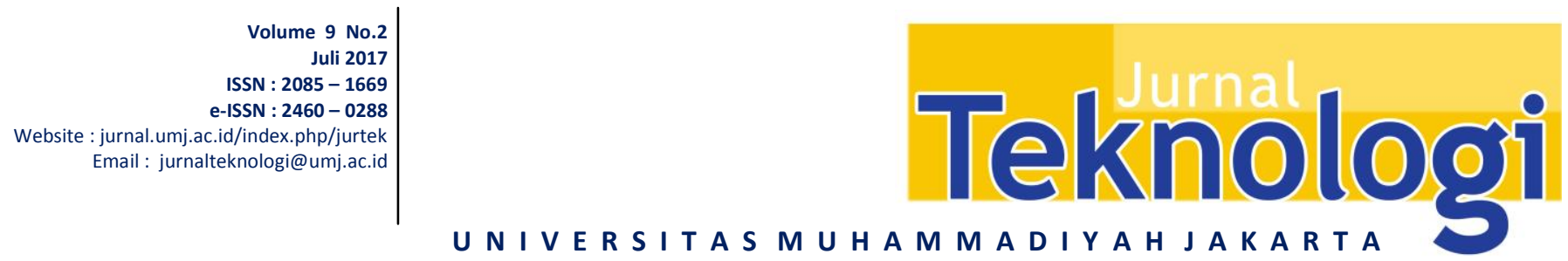

\title{
OPTIMASI SUHU DAN WAKTU STERILISASI PADA KUALITAS SUSU SEGAR DI KABUPATEN BOYOLALI
}

\author{
Tri Yuni Hendrawati ${ }^{1}$, Suratmin Utomo ${ }^{2}$ \\ ${ }^{1,2}$ Jurusan Teknik Kimia, Fakultas Teknik, Universitas Muhammadiyah Jakarta \\ Jl. Cempaka Putih Tengah 27 Jakarta Pusat 10510 \\ *E-mail: yuni.hendrawati@ftumj.ac.id
}

Diterima: 25 Maret 2017

Direvisi: 29 April 2017

Disetujui: 17 Mei 2017

\begin{abstract}
ABSTRAK
Penerimaan susu segar dari peternak atau KUD di Kabupaten Boyolali seringkali mengindikasikan angka TPC (Total Plate Count) yang tinggi, untuk hal tersebut perlu dilakukan penelitian untuk dapat melakukan proses sterilisasi yang masih dapat dilakukan pada toleransi angka TPC tertinggi tetapi tetap mempertahankan rasanya. Tujuan penelitian ini untuk melakukan simulasi penyimpanan pada suhu ruang terhadap angka TPC dan mendapatkan suhu dan waktu sterilisasi terbaik. Metode yang digunakan pada optimasi proses sterilisasi skala Laboratorium dengan dilakukan pengujian bahan baku susu segar, melakukan simulasi pengaruh waktu penyimpanan suhu ruang terhadap angka TPC, melakukan pengujian TPC dan sensori pada pengaruh waktu dan suhu sterilisasi. Pada penelitian ini juga dilakukan pengambilan data sampel susu segar untuk sifat-sifat susu berdasarkan SNI dan hasil pengujiannnya. Hasil pengujian sifat susu segar berdasarkan SNI 3141.1 menunjukkan hasil kualitas susu segar memenuhi kualitas. Kualitas susu di tingkat KUD di Boyolali memenuhi standar kualitas SNI. Pada pengaruh penyimpanan suhu ruang pada waktu penyimpanan 3 jam telah menunjukkan kenaikan jumlah bakteri yaitu 3,5x10 cfu/ml dan mengalami kenaikan pada suhu 4,5 jam dan 6 jam. Pada perlakuan sterilisasi pada suhu $110^{\circ} \mathrm{C}$ selama 10 menit dapat sedikit meningkatkan parameter rasa, warna dan bau. Sedangkan pada parameter kenampakan dan kekentalan sedikit mengalami penurunan dibanding kontrol. Waktu sterilisasi terbaik 10 menit pada suhu $110^{\circ} \mathrm{C}$.
\end{abstract}

Kata kunci: Susu Segar, Sterilisasi, Angka TPC, Pengujian Sensori

\section{ABSTRACT}

Acceptance of fresh milk from farmers or cooperatives in Boyolali often indicates the numbers TPC (Total Plate Count) is high, it is necessary to do research to be able to perform sterilization process can still be done at the highest tolerance TPC numbers but keep the taste. The purpose of this study to simulate storage at room temperature the TPC numbers and get the best sterilization temperature and time. The method used in the sterilization process optimization with the laboratory scale testing of fresh raw milk, simulating the effect of storage time at room temperature with numbers TPC, TPC and sensory testing on the effects of time and temperature sterilization. In this research is also done taking fresh milk sample data for the properties of milk based SNI and the results pengujiannnya. Results of testing the properties of fresh milk by ISO 3141.1 shows the results of quality fresh milk meets quality. The quality of milk at the cooperatives in Boyolali meet ISO quality standards. On the effect of storage at room temperature storage time of 3 hours have shown increases the amount of bacteria that is $3,5 \times 10^{6} \mathrm{cfu} / \mathrm{ml}$ and an increase in temperature of 4.5 hours and 6 hours. In the sterilization treatment at a temperature of $110^{\circ} \mathrm{C}$ for 10 minutes can slightly increase the parameters of taste, color and smell. While the appearance and viscosity parameter slightly decreased compared to the control. Best sterilization time 10 minutes at a temperature of $110^{\circ} \mathrm{C}$.

Keywords: Fresh Milk, Sterilization, Figures TPC, Sensory Testing 


\section{PENDAHULUAN}

Sterilisasi merupakan suatu proses untuk membunuh mikroorganisme sampai ke sporasporanya, yang terdapat di dalam bahan makanan. Proses ini dilakukan dengan cara memanaskan makanan sampai temperatur $121^{\circ} \mathrm{C}$, selama watu 15 menit. Salah satu contoh alat untuk melakukan sterilisasi adalah Autoclave. Pada alat Autoclave ini, bahan makanan dipanaskan sampai temperatur 121$134^{\circ} \mathrm{C}$. makanan diproses selama 15 menit, untuk temperatur $121^{\circ} \mathrm{C}$, atau pada temperatur $134^{\circ} \mathrm{C}$ selama 3 menit. Setelah pemanasan ini, dilakukan pendinginan secara perlahan untuk menghindari over-boiling ketika tekanan diberikan pada makanan.

Susu merupakan bahan makanan yang bernilai gizi tinggi yang diperoleh dari pemerahan hewan, diantaranya sapi. Untuk dapat memperpanjang umur simpan produk susu, maka perlu dilakukan pengolahan (Usmiati, 2010). Menurut Legowo, A.M., 2005, diversifikasi atau penganekaragaman produk olahan susu merupakan salah satu upaya meningkatkan konsumsi susu bagi masyarakat dan berguna bagi produsen dan berbagai pihak yang terkait dalam kegiatan agribisnis dan agroindustri persusuan.

Hingga saat ini. istilah susu sterilisasi belum terdefinisikan dalam SNI tersendiri. Namun secara umum, istilah susu sterilisasi adalah produk olahan susu yang diperoleh melalui suatu proses membunuh mikroorganisme hingga ke spora-sporanya. Proses sterilisasi dilakukan dengan cara memanaskan susu hingga temperatur $121^{\circ} \mathrm{C}$, selama kurun waktu 15 menit. susu sterilisasi biasa dikemas dengan kemasan tetrapack yaitu kardus yang ada lapisan alumunium foil-nya di dalam. Susu jenis ini tidak harus disimpan dalam suhu dingin. Dengan proses sterilisasi memperpanjang umur simpan susu dan dapat menjadi susu untuk anak sekolah dalam membantu pemenuhan gizi bagi anak Indonesia.

Susu steril jenis diproduksi dengan proses perlakuan panas yang biasa disebut dengan Sterilisasi. Proses sterilisasi ini dilakukan untuk membunuh spora bakteri yang terdapat didalam susu. Perlakuan ini memiliki batasan bahwa yang akan rusak karena panas adalah hanya bakteri dan sporanya saja, dan tidak merusak kandungan nutrisi yang berada didalam susu yang ditandai dengan terjadinya perubahan kimia pada susu. Perlu dilakukan penelitian pengaruh masa simpan pada suhu ruang dan waktu serta suhu sterilisasi pada susu segar dalam rangka optimasi proses sterilisasi skala laboratorium.

\section{METODE PENELITIAN}

Sampel susu segar diambil dari salah satu peternak di Kabupaten Boyolali. Penelitian ini dilakukan di Laboratorium Teknik Kimia, Fakultas Teknik, UMJ. Untuk pengujian TPC dan E. coli dilakukan di Laboratorium TIAB, BPPT, Puspiptek Serpong.

Pada penelitian ini dilakukan pengujian kualitas susu segar berdasarkan standar SNI. Susu segar dilakukan perlakuan penyimpanan pada suhu ruang untuk mendapatkan kecepatan kerusakan susu dengan menganalisis TPC pada waktu penyimpanan. Setelah mendapatkan hasil kurva kerusakan susu segar pada suhu ruang maka untuk TPC yang masih memenuhi standar SNI dilakukan pemanasan pada waktu dan suhu sterilisasi sehingga dapat dianalisis TPC, rasa dan kenampakan dan pengujian $\mathrm{E}$. Coli memenuhi standar.

Pengujian TPC yang dilakukan pada berbagai waktu penyimpanan pada suhu ruang untuk mendapatkan kurva grafik laju kerusakan susu segar. Pengujian TPC Susu dilakukan setelah mendapat perlakuan sterilisasi pada berbagai waktu dan suhu. Pengujian E. coli juga dilakukan untuk susu segar setelah proses sterilisasi. Untuk memastikan dari segi rasa maka dilakukan pengujian sensori.

\section{HASIL DAN PEMBAHASAN}

Pada penelitian ini telah dilakukan pengambilan data sampel susu segar dari peternak di Kabupaten Boyolali untuk sifatsifat susu berdasarkan SNI dan hasil pengujiannnya sebagai berikut:

Tabel 1. Hasil Pengujian Sifat Susu Segar SNI 3141.1

\begin{tabular}{lcr}
\hline \multicolumn{1}{c}{ Parameter } & Syarat & $\begin{array}{c}\text { Hasil } \\
\text { Pengujian }\end{array}$ \\
\hline $\begin{array}{l}\text { Berat jenis suhu } \\
27,5\end{array}$ & Min $1,027 \mathrm{~g} / \mathrm{ml}$ & $1,030 \mathrm{~g} / \mathrm{ml}$ \\
\hline
\end{tabular}




\begin{tabular}{|c|c|c|}
\hline Parameter & Syarat & $\begin{array}{c}\text { Hasil } \\
\text { Pengujian }\end{array}$ \\
\hline Kadar lemak & Min 3,00\% & $3.01 \%$ \\
\hline $\begin{array}{l}\text { Kadar berat kering } \\
\text { tanpa lemak }\end{array}$ & Min $7,8 \%$ & $7,82 \%$ \\
\hline Kadar protein & $\operatorname{Min} 2,8 \%$ & $2,98 \%$ \\
\hline $\begin{array}{l}\text { Organoleptik: } \\
\text { warna bau rasa } \\
\text { dan kekentalan }\end{array}$ & $\begin{array}{l}\text { Tidak ada } \\
\text { perubahan }\end{array}$ & $\begin{array}{r}\text { Tidak ada } \\
\text { perubahan }\end{array}$ \\
\hline Derajat keasaman & 6 sampai $7^{0} \mathrm{SH}$ & $6,1{ }^{0} \mathrm{SH}$ \\
\hline Nilai pH & 6,3 sampai 6,8 & 6,4 \\
\hline Uji alkohol $70 \%$ & Negatif & Negatif \\
\hline $\begin{array}{l}\text { Cemaran mikrobia } \\
\text { (total plate count) }\end{array}$ & $\begin{array}{r}\text { Maks } 10^{6} \\
\mathrm{CFU} / \mathrm{ml}\end{array}$ & \\
\hline Uji pemalsuan & Negatif & Negatif \\
\hline Titik beku & $\begin{array}{r}-0,520 \text { sampai - } \\
0,560\end{array}$ & $-0,529$ \\
\hline Uji peroksida & Positif & Positif \\
\hline
\end{tabular}

Pada penelitian ini dilakukan pengujian TPC yang dilkukan pada berbagai waktu penyimpanan pada suhu ruang untuk mendapatkan kurva grafik laju kerusakan susu segar. Hasil pengujian TPC Susus segar pada berbagai waktu penyimpanan pada suhu ruang disajikan pada Tabel 2 dan Gambar 1 berikut.

Tabel 2. Hasil Pengujian TPC Susu Segar pada berbagai waktu penyimpanan pada suhu ruang

\begin{tabular}{ll}
\hline \multicolumn{1}{c}{ Sampel (Perlakuan) } & $\begin{array}{l}\text { Jumlah } \\
\text { bakteri } \\
\text { (cfu/ml) }\end{array}$ \\
\hline $\begin{array}{l}\text { Susu segar-penyimpanan } \\
0 \text { jam }\end{array}$ & $4,9 \times 10^{5}$ \\
\hline $\begin{array}{l}\text { Susu segar-penyimpanan } \\
1,5 \text { jam }\end{array}$ & $1,75 \times 10^{6}$ \\
\hline $\begin{array}{l}\text { Susu segar-penyimpanan } \\
3 \text { jam }\end{array}$ & $3,5 \times 10^{6}$ \\
\hline $\begin{array}{l}\text { Susu segar-penyimpanan } \\
\text { 4,5 jam }\end{array}$ & $3,45 \times 10^{7}$ \\
\hline $\begin{array}{l}\text { Susu segar-penyimpanan } \\
6 \text { jam }\end{array}$ & $1,75 \times 10^{8}$ \\
\hline
\end{tabular}


Pengujian sensori perlu dilakukan dalam rangka menjaga rasa susu dapat dipertahankan. Hasil pengujian sensori susu hasil sterilisasi disajikan pada Tabel 5 berikut

Tabel 5. Hasil pengujian sensori susu

\begin{tabular}{lllllll}
\hline Kode Rasa & Warna & $\begin{array}{l}\text { Penam } \\
\text {-pakan }\end{array}$ & $\begin{array}{l}\text { Keken- } \\
\text { talan }\end{array}$ & Bau & $\begin{array}{l}\text { Skor } \\
\text { keselu - } \\
\text { ruhan }\end{array}$ \\
\hline 342 & 4,5 & 5 & 5 & 5 & 3 & 22,5 \\
\hline 535 & 6 & 4 & 4 & 2,5 & 5 & 21,5 \\
\hline 758 & 5 & 5 & 5 & 5 & 4,5 & 24,5 \\
\hline 691 & 6 & 5,5 & 4 & 4 & 5,5 & 25 \\
\hline
\end{tabular}

Keterangan : Kode 758 pada waktu 0 jam, 342 pada $1,5 \mathrm{jam}, 691$ suhu sterilisasi $110^{\circ} \mathrm{C}$ waktu 10 menit, 535 suhu sterilisasi $120^{\circ} \mathrm{C}$ waktu 10 menit. Skala skor 1-10 dimana 1 tidak baguas, 5 netral dan 10 semakin tidak bagus

Intepretasi pada penilaian parameter rasa, susu dengan kode 691 dan 535 memiliki skore penilaian rasa skala 6 yang berarti rasa susu agak bagus. Sedangkan susu dengan kode 342 memiliki skore penilaian 4,5 yang berarti rasa susu agak kurang bagus. Pada pengamatan parameter warna, susu dengan kode 691 memiliki penilaian paling tinggi yaitu 5,5. Sedangkan susu dengan kode 535 memiliki penilaian paling rendah (4), yang berarti warna susu tidak bagus dibanding yang lainnya.

Pada penilaian kenampakan susu dengan kode 342 dan 758 memiliki skor 5 sedangkan 535 dan 691 mendapat skore 4. Hal ini menunjukkan kenampakan susu dengan kode 342 dan 758 lebih baik dari 535 dan 691. Pada penilaian parameter kekentalan, susu dengan kode 342 dan 758 memiliki skore 5 sedangkan susu dengan kode 691 dan 535 memiliki skore lebih rendah yaitu 4 dan 2,5. Susu dengan kode 535 memiliki penilaian kekentalan yang tidak bagus.

Pada parameter bau, penialaian paling tinggi adalah susu dengan kode 691 dan paling rendah adalah 342. Dari keseluruhan penilain dapat diambil kesimpulan bahwa susu dengan kode 691 memiliki penilaian secara keseluruhan paling tinggi dan sedikit lebih baik dari kontrol (kode 758). Sehingga perlakuan sterilisasi pada suhu $110^{\circ} \mathrm{C}$ selama 10 menit dapat sedikit meningkatkan parameter rasa, warna dan bau. Sedangkan pada parameter kenampakan dan kekentalan sedikit mengalami penurunan dibanding kontrol.

\section{KESIMPULAN}

Hasil Pengujian Sifat Susu Segar ditingkat peternak di Boyolali berdasarkan SNI 3141.1 menunjukkan hasil kualitas susu segar memenuhi kualitas. Pada pengaruh penyimpanan suhu ruang pada waktu penyimpanan 3 jam telah menunjukkan kenaikan jumlah bakteri yaitu $3,5 \times 10^{6} \mathrm{cfu} / \mathrm{ml}$ dan mengalami kenaikan pada suhu 4,5 jam dan 6 jam. Pada perlakuan sterilisasi pada suhu $110^{\circ} \mathrm{C}$ selama 10 menit dapat sedikit meningkatkan parameter rasa, warna dan bau. Sedangkan pada parameter kenampakan dan kekentalan sedikit mengalami penurunan dibanding kontrol. Waktu sterilisasi terbaik 10 menit pada suhu $110^{\circ} \mathrm{C}$.

\section{UCAPAN TERIMA KASIH}

Terima Kasih kepada Universitas Muhammadiyah Jakarta, Kopertis Wilayah III, Kementerian Ristek Dikti atas pembiayaan penelitian ini sesuai dengan Surat Perjanjian / Kontrak Penugasan dalam Rangka Pelaksanaan Program Penelitian Tahun Anggaran 2016 Nomor 772/K3/KM/SPK.LT/2016 Tanggal 14 Juni 2016.

\section{DAFTAR PUSTAKA}

Austin JE. 1992. Agroindustrial Project Analysis: Critical Design Factors. EDI Series in Economic Development. The Johns Hopkins University Press. Baltimore and London.

Branan CR. 1994. Rules of Thumb for Chemical Engineers, A Manual of Quick, Accurate Solutions to Everyday Process Engineering Problems. Gulf Publishing Company. Houston, Texas

Brown J G, Deloitte, Toache. 1994. Agroindustrial Investment and Operations. Washington DC : EDI Development Studies.

Chandan, R. C, 2011, Dairy Ingredients for Food Processing: Chapter 1. Dairy Ingredients for Food Processing: An Overview. 
Dieter GE. 1987. Engineering Design, A Material and Processing Approach. First edition. McGraw-Hill Book Company. New York.

Douglas JM. 1998. Conceptual Design of Chemical Processes, Mc Graw Hill International Edition. Chemical Engineering Series.

Edgar TF and Himmelblau DM. 1988. Optimization of Chemical Processes, Chemical Engineering Series. Mc Graw Hill International Edition.

Gosta Bylund, MSc, 1995, Dairy Prosessing Handbook, Tetra Pak Processing Systems AB S-221 86 Lund, Sweden

Hadiwiyoto,S. 1982, Teknik Uji Mutu Susu dan Hasil Olahannya, Universitas Gajah Mada Press, Yogyakarta

http://www.azaquar.com/en/iaa/index.php?cibl e=ta_laiterie_03\#_Toc222116729, diakses 28 Juni 2015

Lewis, M.J. dan Deeth, H. C. Milk Processing and Quality Management: Chapter 7. Heat Treatment of Milk. Edited by $\mathrm{Dr}$ Adnan Y. Tamime, Advance Dairy Science and Technology

Pisekey, J, 1997, Handbook of Milk Powder Manufacture, Copenhagen, Denmark

PT. Sari Husada Tbk, 2003, Proses Pengolahan Susu Bubuk, Yogyakarta

Saaty TL. 1993. Pengambilan Keputusan Bagi Para Pemimpin: Proses Hirarki Analitik untuk Pengambilan Keputusan dalam Situasi Yang Kompleks. Setiono L, penerjemah; Jakarta: Pustaka Binaman Presindo.Terjemahan.

Seider WD, Seader JD and Lewin DR. 1999. Process Design Principles Synthesis, Analysis and Evaluation. John Wiley \& Sons, Inc.

Sinnott RK. 1989. Chemical Engineering, An Introduction to Chemical Engineering Design. Pergamon Press Oxford. New York.

SNI 3141.1.2011, BSN 
